\title{
Strengthening Endogenous Regional Development in Western Mexico
}

\author{
Peter R.W. Gerritsen \\ Departamento de Ecología y Recursos Naturales - Imecbio, \\ Centro Universitario de la Costa Sur, \\ Universidad de Guadalajara, \\ Mexico
}

\section{Introduction}

Much has been written on the negative effects of globalization in the Mexican countryside, showing the multi-dimensionality of the problems generated, noting not only the economic effects, but also the socio-cultural and ecological repercussions, which have to do with various issues related to rural life and production, such as the quality of rural producers' life, identity and traditional practices, or sustainable natural resource management (Cortez et al., 1994; Schwentesius et al., 2003; Esteva \& Marelle, 2003). Additionally, reference is also made to the trans-national nature of the problem, emphasizing the involvement of processes that go beyond the regional and national territory (Halweil, 2000; Schwentesius et al., 2003). Table 1 presents an overview of (some of) these negative effects, as identified from bibliography.

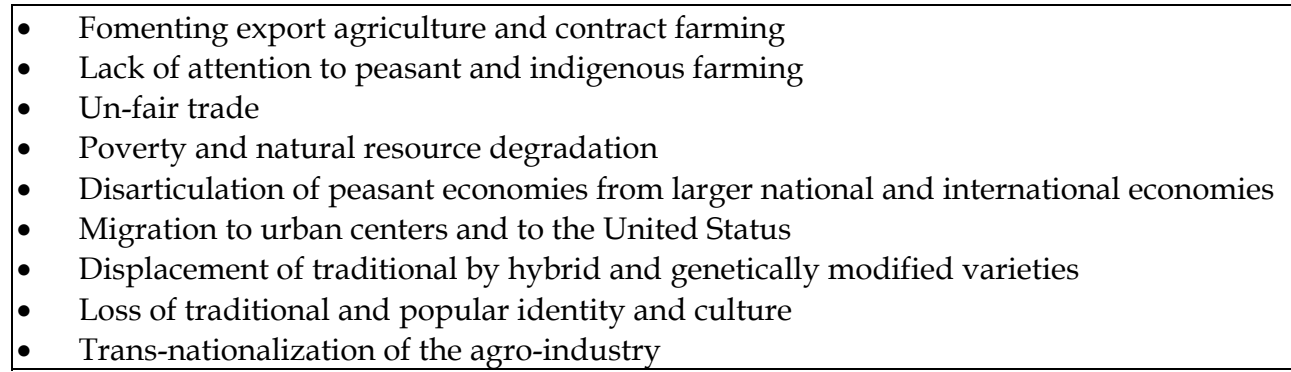

Table 1. An overview of some of the negative effects of economic globalization as identified from bibliography (Cortez et al., 1994; Schwentesius et al., 2003; Esteva \& Marelle, 2003; Jansen and Vellema, 2004; Halweil, 2000)

These negative effects contest the process of economic globalization as related to rural actor's livelihood strategies, and as related to the natural resources on which they depend (Toledo, 2000; Carabias \& Provencio, 1993). It also questions the capacities of governmental institutions to offer pertinent solutions. Moreover, it gives rise to the idea that overcoming poverty, increased production, appropriate technology development, and farmer participation requires profound social and institutional adjustments. More specifically, this 
requires a development model that is able to respond to the specific necessities of the rural sector, as well as one that is able to develop strategies that strengthen governmental intervention in favor of sustainability (Muñoz \& Guevara 1997; Gerritsen et al., 2003).

Although it goes beyond discussion to deny the negative effects of economic globalization, an increasing number of social actors can be identified at the local levels, which look for alternative strategies to restrain from the negative effects (Toledo 2000; Gerritsen et al., 2004). These actors have developed a number of responses and strategies, which can be conceptualized as efforts to construct viable and sustainable alternatives for a different social order in the local territory (Cortez et al.,1994; Morales, 2004; Waters, 1995).

This chapter's main interest and focus lies on describing and understanding those local experiences that hold the possibility to develop and strengthen development models that may serve as a platform for the designing new agricultural policies that better respond to the social, economic and environmental challenges present in different territories (cf. van der Ploeg \& Long, 1994). It presents an overview of an action-research program that has been implemented by personnel of the Rural Development Group of the Department for Ecology and Natural Resources (DERN-IMECBIO, according to its Spanish acronym) at the South Coast University Campus (CUCSUR, according to its Spanish acronym) of the University of Guadalajara. The work of our group has consisted of supporting local initiatives to construct viable alternatives in the South Coast of Jalisco, located in western Mexico. ${ }^{1}$

In the following pages I will presen some theoretical notions, followed by four different thematic working fields of local development that have been supported and studied by us. The chapter finishes with a discussion and a conclusion, aiming at locating the different thematic experiences within current theoretical debates on the local effects of economic globalization.

\section{Endogenous rural development and the farm enterprise}

In general terms, farm production makes up the mobilization of resources, the enrollment of farmers in the agro-food chain in order to sell their produce, and contributes to the creation and maintenance of rural identity and rural social organization (van der Ploeg et al., 2002) (Figure 1).

Originally, farming production was based on diversified, rather autonomous strategies (Toledo, 1990). In other words, endogenous forces were at the heart of rural development (van der Ploeg, 1994). Furthermore, one can also speak of endogenous rural development. Endogenous rural development is understood here as a development model that departs from local natural resource use and management, local actors' capacities and abilities to develop strategies for the appropriation of material and non-material resources, and where there exists local actors' control on (the value of) the farming production (van der Ploeg \& Long, 1994).

\footnotetext{
${ }^{1}$ This chapter compiles part of fifteen year's research and extension work experience of the Community Development Group. The author of this paper took up the task to compile the experience gained over the years in this second English written version (see Gerritsen, 2006 for the first version). This paper was published before in Spanish in different versions and forms, see Villalvazo et al. (2003); Gerritsen et al. (2004, 2005a. 2005b); and Figueroa et al. $(2003,2004)$. The theoretical foundations of the work are described in Gerritsen (2010).
} 


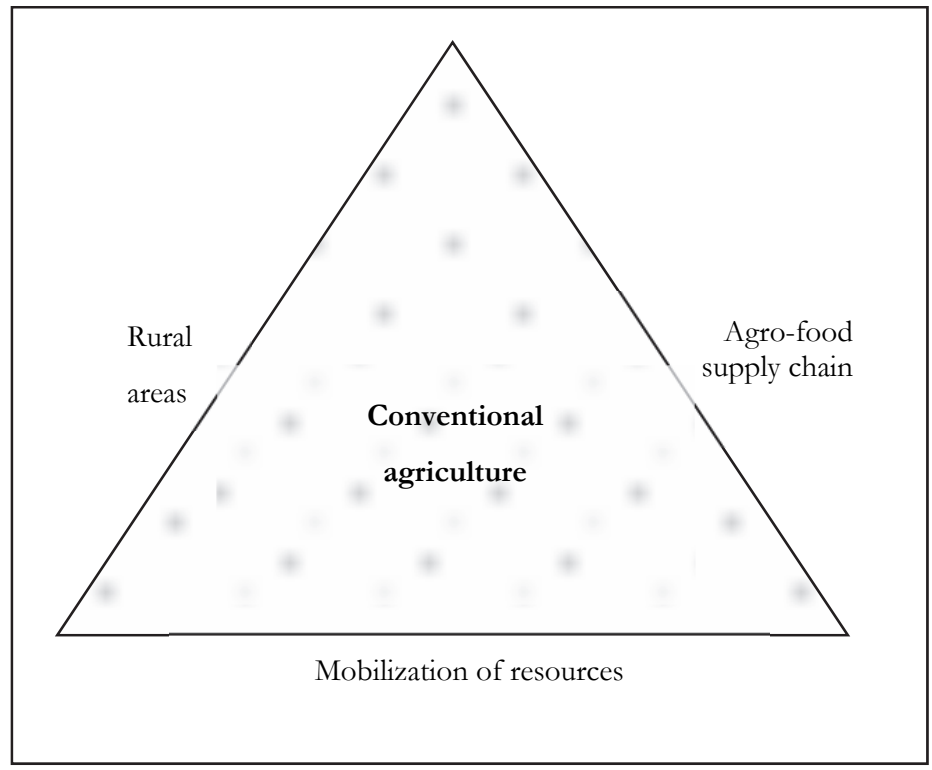

Fig. 1. The three sides of the agricultural enterprise (van der Ploeg et al., 2002: 12)

Generally speaking, there are four dimensions of rural development (either endogenous or not) and they have to deal with the available natural resources in the locality (that is, the domain of farm production and the domain of farm reproduction), the interaction of farmers with other (external) actors and institutions, and the incorporation in different markets (that is, the domain of economic and institutional relations), the maintenance of traditions and certain identity, and finally, an idiosyncratic and specific vision of the world in general and agricultural work in particular (that is, the domain of family and community relations) (van der Ploeg, 1990) (Figure 2).

In the local territory, endogenous potential can be understood as a specific configuration of the different farming domains (and the great many different farming activities that each one of these domains includes), created and coordinated purposefully by local actors. The outcome of this domain coordination is the conformation of specific farming styles, which are to be understood as purposeful socio-productive strategies. A central characteristic of farming styles is the close bond between manual and mental labor, i.e. the close relationship between farming discourse and practice (van der Ploeg, 1994). ${ }^{2}$

Aside from its close bond with farmer strategies, endogenous potential for rural development can also be located in different links of the productive chain ${ }^{3}$. The endogenous potential of productive chains refers to those products that arise from the local territory, and

2 Due to this close relationship, endogenous rural development and farming styles are studied by us by applying an actor-oriented perspective (Long \& Long, 1992; Long, 2001).

3 A productive chain is understood here as: "a system constituted by interrelated actors [...] and by a succession of operations of production, transformation and commercialization of a product, or a group of products, [developed] in a given surrounding" (Heyden et al., 2004: 11). 
where production, transformation and commercialization activities are carried on with an actor's own resources and by departing from trans-generational knowledge, and, moreover, where the consumers recognize these products as typical or authentic for the region. ${ }^{4}$

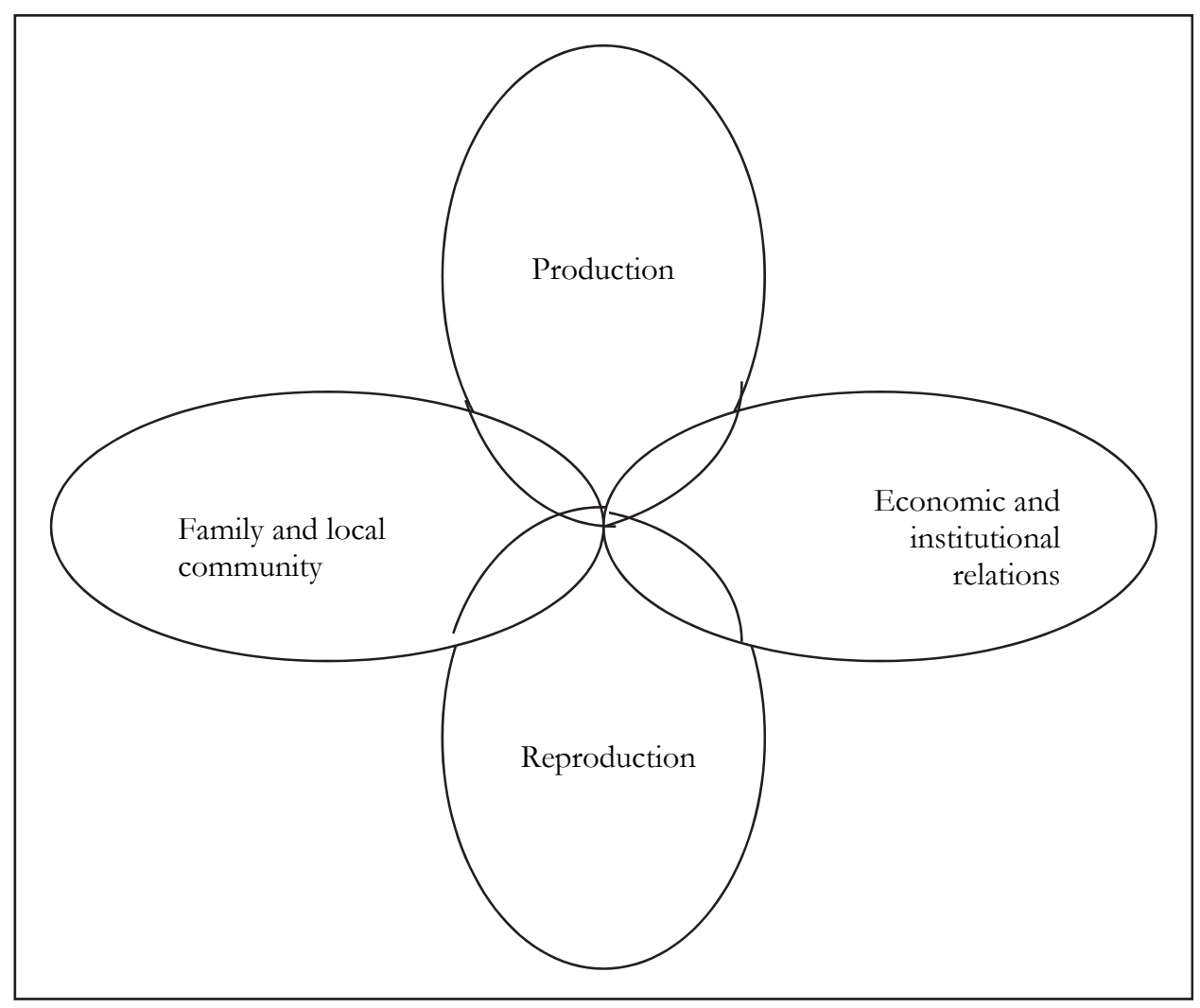

Fig. 2. The domains of farming (van der Ploeg, 1990: 29)

Development models implemented as part of economic globalization have impacted in different grades and in different moments on rural and indigenous production ${ }^{5}$ and have aimed at substituting these with agro-industrial methods ${ }^{6}$, causing the ecological, social,

\footnotetext{
${ }^{4}$ Opposed to productive chains that are disconnected from the local territory, where inputs are external and knowledge is based mainly on science and technology. It is these kinds of productive chains where the great majority of the high socio-environmental costs of production, transformation and transportation can be located, with the goal to reach consumers all over the world (Halweil, 2000).

${ }^{5}$ The peasant (or indigenous) production mode is understood here as those production systems that are based on diversification, local resource use, family labor, and subsistence-oriented production (Toledo, 1995).

${ }^{6}$ The agro-industrial (or modern) production mode is understood here as those production systems that are based on specialization, external resource use, the use of hired farm laborers, and where a commercial production orientation prevails (Toledo, 1995).
} 
economic and cultural consequences mentioned before in Table 1 (Calva, 1993; SaxeFernández, 1998; Morales, 2002). From the perspective of sustainability, the agro-industrial development model for consolidating the "modernization of the Mexican countryside" can be considered non-viable and extremely harmful in all its dimensions (Toledo, 2000).

Economic globalization processes affect the endogenous potential of a specific territory by changing the locally-specific ecological, social and socio-institutional, cultural, and ethical conditions. In others words, it induces a reconfiguration of the social relations of production, as well as the social and material bases of production. As a consequence, new intraregional - farming styles can arise. At the same time, it can change the conditions of the different links of the productive chain, affecting the patrimonial values of the region. Figure 3 illustrates this by presenting normatively defined development patterns for farming styles in relation to diversity in natural resources.

In order to strengthen regional sustainable development initiatives that depart from the endogenous potential in local territories, it is necessary to design and implement productive alternatives that built upon existing social, economic, cultural and environmental processes, which implies strengthening traditional knowledge, improving traditional technology for family agriculture, generating viable peasant economies, reactivating regional economic dynamics, strengthening a culture of self-sufficiency and one that builds upon and strengthens a harmonious interrelation and respect for living nature (Morales, 2001; Toledo, 2003). In our work, efforts have been directed at four thematic fields of action that relate to these different fields of attention: agroecology and fair trade (aimed at strengthening farm reproduction and production), gender and natural resource management (aimed at incorporating the gender issue in our work), appropriate technology development and, finally, regional production and territorial value recuperation. Within these different thematic fields, various theoretical-methodological tools have been applied. 7 In the following sections, I will describe our different experiences in these fields.

\section{Agroecology: Strengthening the reproductive and productive base of farm enterprises $^{8}$}

In the reproduction (and production) link of the productive chain, agro-ecology has been the starting point of our work, and, in lesser degree, the related field of fair trade. Following Guzman et al. (2000), the restoration of essential ecological processes of agro-ecosystems is the first step in the revalorization of traditional farming systems, where endogenous elements predominate over the exogenous ones.

This thematic field originates in the beginning of 2001, as a response to the social demands of an indigenous community in the region where we live and work. Until now, activities to

\footnotetext{
7 This is explained by Rist (2004), who mentions that in the literature on endogenous development, attention goes mostly to "what to obtain", rather than describing "how to do it". Therefore, a great variety of methodologies is potentially useful for identifying, strengthening and evaluating endogenous development initiatives, whose choice depends on the specific characteristics of the local territory (Broekhuizen \& van der Ploeg, 1995).

${ }^{8}$ Based on Figueroa et al. (2004).
} 


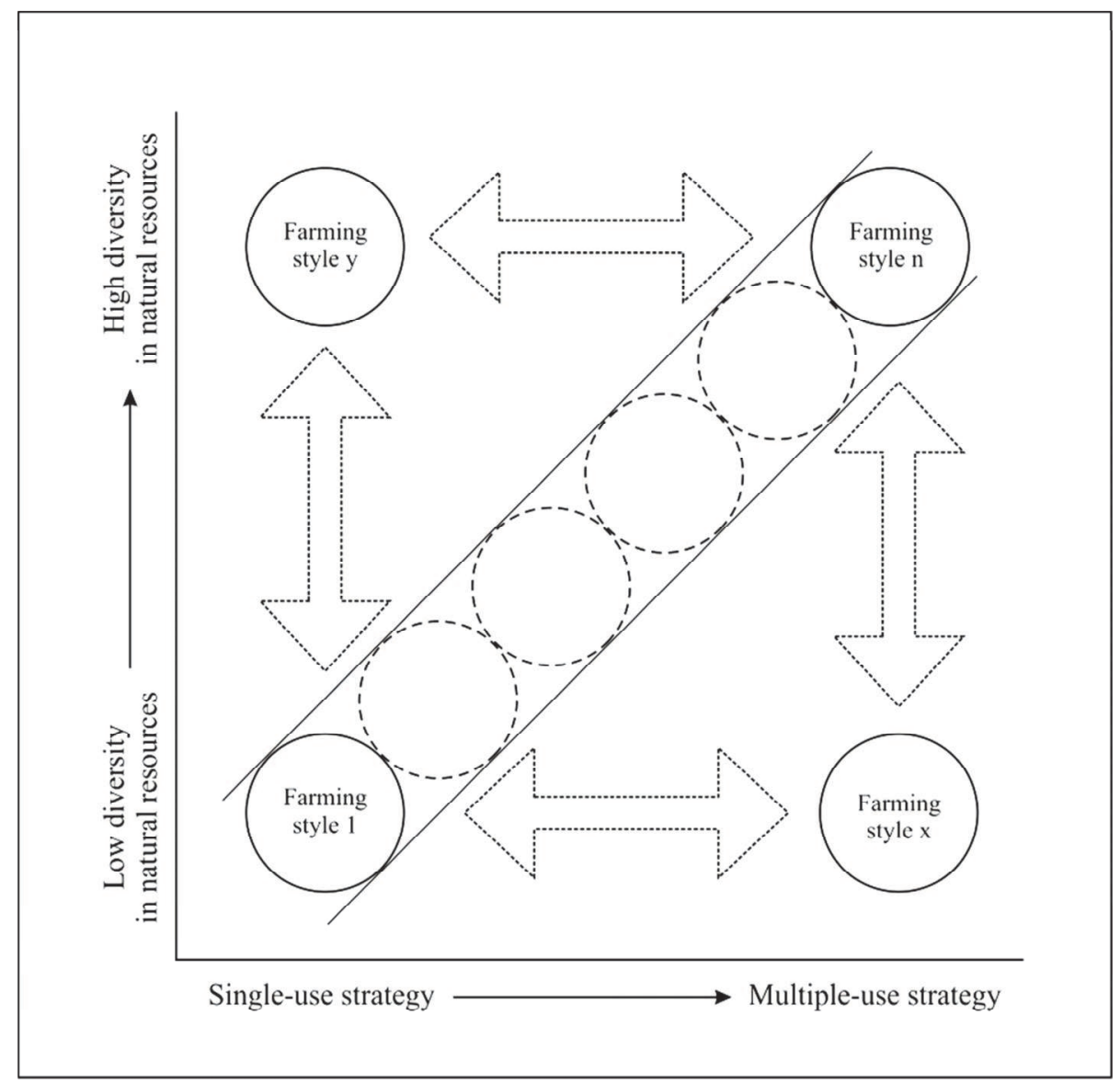

Fig. 3. Normatively defined development patterns for farming styles in relation to resource diversity (Gerritsen, 2002: 27)

improve the soil and the quality of local foods have been carried out, and have spread to other communities. Farmer training workshops are an important part of the work and are realized by (professional) advisers and by farmer extensionists.

The recuperation of traditional ecological knowledge and practice is oriented towards the revalorization of local knowledge, in addition to the advisory work, allowing a permanent dialogue between the different parties. Likewise, following Restrepo (1998), it is the farmers themselves, who discover the main problems that affect them. Moreover, it is these farmers who set the priorities and look for solutions, or demand a solution to external institutions, when not locally available.

A central activity has been the development of organic fertilizers elaborated with local materials and knowledge. The diverse ways in which farmers have are prepared organic 
fertilizers reflects the non-existence of fixed recipes. Additionally, it reflects farmer experience, their problem-solving creativity and the traditional knowledge put to use in daily practice, demonstrating great skill and capacity for self-management.

In addition to the preparation of organic fertilizers, the importance of traditional knowledge on nature observation, and the importance of the moon in agriculture, that is, each one of its phases and consequent influence on plant and the animal growth, has been strengthened by thematic workshops. Furthermore, the importance placed on preventing the burning of crop residues has favored crop association recovery and allowed reflection on the necessity to diversify not only crops, but also animal use within the household. Likewise, level curve ploughing was realized by promoting the "A-apparatus" to avoid erosion in steep areas.

The different agro-ecological proposals for sustainable development have been promoted by us as suggestions, recommendations, or as a guide, and can be used and developed according to the specific conditions of participating farmers, without creating an artificial separation of agricultural work from the daily of rural communities.

Several years after having initiated the activities described, a number of lessons can be learned, of which we want to mention the following:

- The importance of the recovery of crop diversity: we found a greater diversification in maize cultivation fields of participant farmers, amongst others, due to the abolishment of chemical herbicides. Associations of crops that have been established include: maize, bean, Jamaica (Hibiscus sp.), cucumber, tomato, pumpkin, banana and blackberry.

- The abolishment of fire as a practice to eliminate crop residues and weeds: this practice has been reduced by those farmers that have participated in the different workshops, and has favored the incorporation of organic matter into the soil.

- The trace of level curves, with the use of A-apparatus. This practice diminishes soil erosion, together with the use of dead and live fences.

- $\quad$ The incorporation of organic fertilizers, elaborated by participants.

It is important to mention that these practices have obtained relevance in the sense that they have reinforced farmer autonomy and independence and have contributed to a revalorization of manual (family) labor. For example, all the cleaning in the parcel was performed manually, a fact that furthermore reinforces the incorporation of organic matter to the soil and replaces the use of (chemical) fertilizer and pesticides. The adoption of the organic fertilizers by the producers of several communities has many perspectives to continue advancing, due to the flexibility in the use of supplementary local resources to elaborate the organic fertilizers, as we already mentioned before.

\section{Gender relations in small-scale projects ${ }^{9}$}

Rural development policies do not only affect male, but also female farmers, although the majority of the policies is directed mainly at the former (Moser 1993; Kabeer 1998). It is for this reasons that our work has included a gender dimension, in order to strengthen the position of women in different societal spaces, such as: citizen participation and decision making, community leadership, and access, use and control of natural resources, among others (Enríquez, 2000).

\footnotetext{
${ }^{9}$ Based on Reyes et al. (2004).
} 
Since 1995, several actions have been established with a group of women farmers in one of the indigenous communities in the region, directed at reinforcing production strategies based on the reality and the necessities suggested by the women. These actions have consisted in supporting women solely, but also include mixed - male and female - farmer groups, in developing small-scale projects, such as: organic coffee, embroidery, natural conserves, organic honey, and traditional medicine.

Within the projects, women are not perceived as passive objects of development, but as active actors who have capacities and abilities to modify their socio-material surrounding, based on their knowledge of the specific characteristics of their natural surroundings, and their definition of strategies in order to interact with different local and governmental actors (cf. Long \& Long, 1992; Long, 2001).

The actions within this thematic field are oriented to reinforce coherent strategic necessities of the participant women farmers. This includes the following activities:

- Supporting the organization of the group of women;

- Training the different groups, both women solely and mixed in order to strengthen production, administration and commercialization capacities;

- Generation of mechanisms for active and constructive participation of women, allowing a change of the women's social position in their community.

As mentioned before, these strategies were translated into a number of small-scale development projects, which for the sake of feasibility were established initially within the frame of the family production. Not only economic benefits have been derived from the productive projects, but there has also been the systematization of a series of social indicators that allow us to establish a retrospective reflection of the process of the on-going work with the women.

Furthermore, the inclusion of a gender approach in our actions has allowed a valorization of the contribution of women farmers to be strengthened further. Although the small-scale projects have turned around family production, throughout time it has become clear that the strategic needs of the women farmers have to be addressed also in the training workshops implemented.

\section{Endogenous rural development and technology development ${ }^{10}$}

Endogenous rural development not only requires the strengthening of the reproductive and productive base of the farm enterprise, or giving attention to the role of male and female farmers. It also has to deal with the development of appropriate technology (Pretty 1995). Generally speaking, technology is understood here as a combination of a number of techniques and the knowledge to apply these techniques.

Firewood is one of the most frequently used renewable resources in rural areas and one of the aspects to be considered here is the type of technology used for its burning. Traditional stoves are inefficient in their energy consumption and have a negative impact on human health. For this reason we started to promote improved firewood stoves, called "Estufas

${ }^{10}$ Based on Figueroa et al. (2003). 
Lorena". The Lorena stoves use less firewood and have decreased the negative health effects associated with fire smoke. They can be considered as a technology that is appropriate to local conditions.

Our work in promoting the Lorena stoves in the Southern Coast of Jalisco has increased the understanding of the problem with firewood collection, especially related to women farmers, as well as the inconveniences of traditional stoves. Collection and the nuisance of smoke in the kitchen were mentioned as two major problems regarding firewood and its burning.

Until now, a total number of approximately 250 Lorena stoves have been built in the region, illustrating the possibilities of fomenting appropriate technology amongst peasant and indigenous farmers.

According to results, Lorena stoves reduce firewood use up to $70 \%$, in comparison to traditional stoves. Besides, the improved firewood stoves have substantially improved the health of farmers, especially women. While the introduction of the Lorena stove has been a success, farmers do not directly relate its functioning with natural resource conservation (through there was an observed decrease in the firewood necessities). This stresses the need for incorporating a environmental education component in our work.

\section{Endogenous development and regional agricultural and artisanal production $^{11}$}

There are a great diversity of products, which are produced in the region. These products, called here regional products, can be local foods and beverages, with typical recipes that have a limited geographic distribution with respect to his elaboration. We also include ceramics, embroidery, furniture and other handmade products (cf. van der Meulen, 1999).

Regional production can be divided into three categories. First, many of the regional products are the product of agricultural work, elaborated by individuals, families or by groups of farmers who live in rural zones. Secondly, in urban zones we found the second category, i.e. to be the typical occupations, for example, baker or butcher. In these cases, importance is attributed to preparation or elaboration of certain product, rather than the origin of the resources. Finally, the third category consists of those regional products in urban zones that are commercialized by small entrepreneurs. These can consist of products that are traditional for a region or products that carry the name of the region, showing their origin in a given region (ibid.). It is worth noting that the different categories are not mutually exclusive, and it is not always totally clear in which of the three categories a specific product belongs.

So far, we have described 32 regional products, which represent a first approximation in the Southern Coast of Jalisco (and part of the neighboring state of Colima) in regards to understanding of how actors respond to economic globalization that affects them in one way or another in the local territory.

With respect to the characteristics of regional production, a statistical analysis suggests the existence of two large groups. On the one hand, we found a group of producers and

${ }^{11}$ Taken from Gerritsen et al. (2004, 2005a). 
businessmen that use an advanced process of industrialization, and who are located mainly in urban zones. Products of this group are characterized by a high exchange value. Additionally, specialist dominates this group. On the other hand, we found a second group comprised of those actors whose products are characterized by a high use value. These actors do not use a very advanced industrialization process; rather they take advantage of locally available resources. In other words, the logic of this group is geared toward home consumption, and they only commercialize surplus produce. Additionally, the activities of this group are more related to farming, and, as such, this group is mainly found in rural zones.

Our analysis further suggest that the activities of the first group (the specialists in urban areas) requires a considerable economic investment and constant acquisition of inputs for production and commercialization, meanwhile most products in the rural zones are developed more or less in a context of economic limitations and with a predominant use of their own resources.

Many of the regional products can be considered as "novelties" (Swagemakers, 2002). With this term, reference is made here to specific changes made by an actor in the production process with the purpose of reaching a desired situation. In order for a novelty to develop, a "niche" is required, that is specific local conditions where the idea can emerge and the fabrication of a regional product can take place. It does not only require a favorable context, but also time so that the development of a regional product can mature. Third, the development of a regional product is closely related with insecurity in or vulnerability of livelihood strategies, in both production and commercialization (Wiskerke \& van der Ploeg, 2004). As such, many of regional products are a result from constant experimentation. These three elements, novelty - niche - insecurity are highly related with the life histories of the social actors who produce and commercialize these regional products.

\section{Understanding endogenous rural development initiatives}

In the foregoing, we described the four thematic work fields we have been working with, which aim to support and strengthen endogenous rural development initiatives in the Southern Coast of Jalisco. These different experiences can be considered as different strategies of valuation, and use and management of natural resources in local territories. Furthermore, these strategies depart from the existing endogenous potential in the local space, which can be characterized by a productive autonomy, maintenance of identity and local culture, and strong roots to the local area. In relation to the latter, a fundamental difference is observed with those strategies, where the mobilization of resources is based on organization outside of the local area. In these latter cases, resources are not only mobilized outside the territory, but also the production (and reproduction), transformation and commercialization, including economic and institutional relations and the family or community relations that accompany it. The latter implies that any effort to strengthen endogenous rural development initiatives allows revaluing the social, economic and ecological characteristics of local territories, i.e. it involves a revaluation of multi-functional nature of these areas.

The endogenous rural development initiatives as developed by the social actors supported show a farming domain coordination (Figure 2) that is different than that of conventional 
producers (Figure 1). Compared to the latter, analytically one can state that endogenous development initiatives are characterized by a "broadening", a "deepening" and a "regrounding" of the different farming activities, as illustrated by Figure 4.

Following van der Ploeg et al. (2002), the broadening of farming activities refers to the incorporation of new farming activities into the farming domains, such as agri-tourism, care activities, diversification or nature and landscape management activities. Deepening refers to the aggregation of new values to the farm, as a consequence of the shift to organic farming, the elaboration of high-quality and regional products, and the shortening of the supply chains. Finally, the re-grounding of farming practice refers to the substitution of certain values for others, such as, for example, new forms of cost-reduction, off-farm income sources and new forms of co-operative management.

In our case, a deepening and re-grounding of farming practice characterize the endogenous development initiatives in the Southern Coast of Jalisco. Deepening refers to the elaboration of organic and regional products, as well as the search for fair trade commercialization initiatives. Furthermore, re-grounding takes place by the substitution of chemical by organic fertilizers, as well as the use of Lorena stoves. It also takes place by through the association of women farmers around common productive issues.

Retaking Figure 2, a (qualitative) assessment of the sustainability of endogenous rural development initiatives can also be made, as compared to conventional agricultural practices (Gonzalez, 2006). Figure 5 presents a qualitative comparison of four crops that are important in the region, including the underlying livelihood strategies, as well as their environmental impact.

Comparing organically cultivated peanuts and maize with agro-industrially produced melon and agave in relation to single-use vs. multiple-use strategies (i.e. specialization vs. diversification) and the presence of a low vs. high diversity in natural resources (i.e. enrichment vs. degradation of the natural environment) shows that the endogenous rural development initiatives are characterized by diversification and environmental enrichment, while melon and agave are specialized and degrading farming systems.

\section{Towards a new emergent rurality}

Until now, we presented a general description of the endogenous rural development program, as well as the different initiatives supported by us, through training, organization and applied research. However, the strengthening of endogenous rural development initiatives goes beyond mere training and organization of different farmer groups with whom we work. It has relates to the topic of "rurality", that is to say, our understanding of and actions associated with "the rural". Generally speaking, we understand "rurality" referring to the social representations of rural zones, which relate to existent dynamics and socio-materials processes (van der Ploeg, 1997). In the case of Mexico, reflecting about existing rurality is important, due to the deep transformations to which the Mexican countryside is submitted, and which are due to neo-liberal development and economic globalization processes (Schwentesius et al., 2003; Esteva \& Marielle, 2003). 


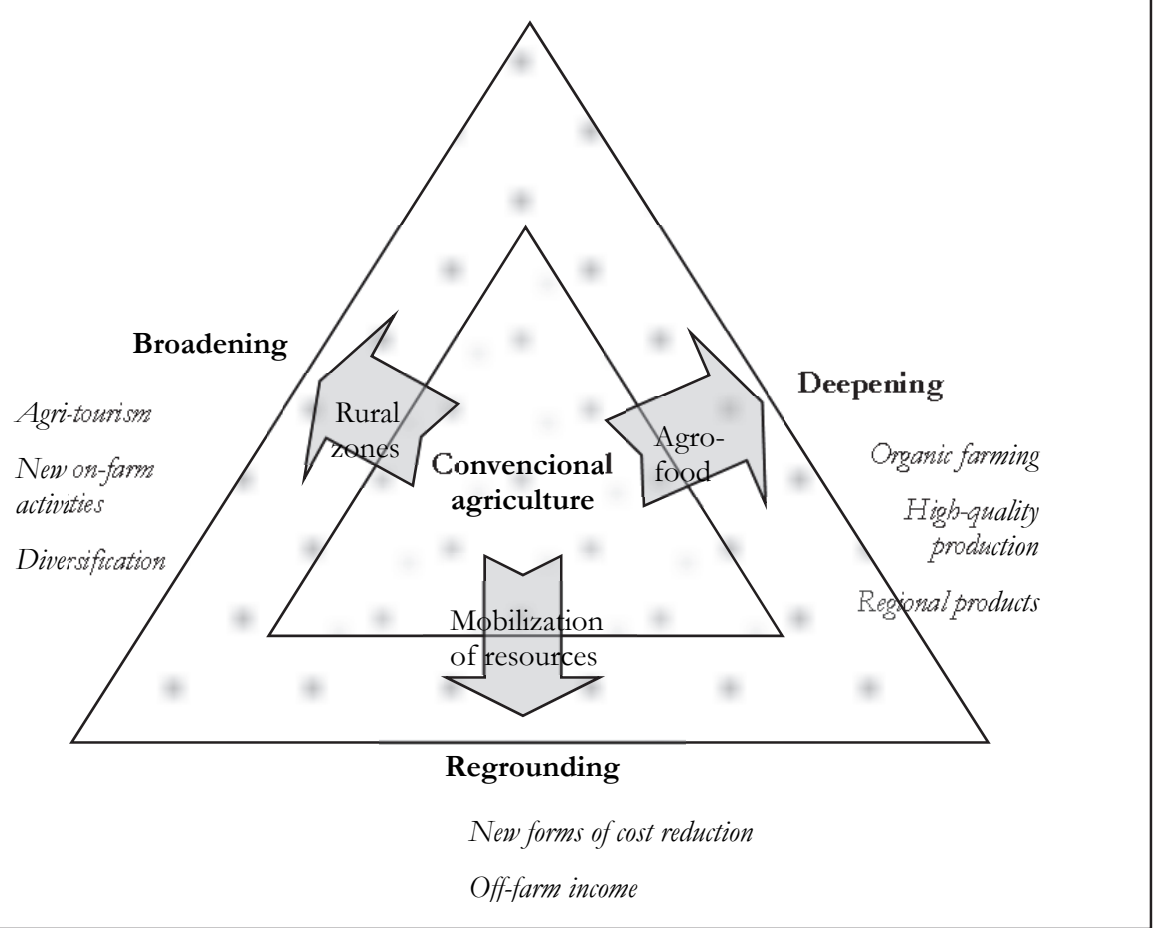

Fig. 4. The structure of rural development at farm enterprise level (van der Ploeg et al., 2002: 12)

Our work in the South Coast of Jalisco suggests the presence of a new emergent rurality where the endogenous properties form the essence. As such, we understand rurality as being the result and expression of a co-production process, i.e. the on-going interactions and mutual transformations between man and nature in the local area, and where farmers play a strategic role. It is through the process of co-production that the typical (cultural) landscape of a region comes to life, or where an unique (agro-) biodiversity is being created (van der Ploeg, 1997; Gerritsen, 2002). Moreover, it has multiple benefits, such as the generation of local employment; the generation of income articulated to the regional economy, the maintenance of culture and local identity, and the conservation of natural resources, amongst others.

We assume that this new rurality is emergent as it appears there is an increasing number of producers who look for developing alternative models of production, transformation, and industrialization. The strategies of these actors include an appropriation of local territory's patrimonial values and the (re)valuation of its natural resources ( $c f$. Casablanca \& Linck, 2004). In this context, the absence of a favorable institutional context to strengthen these experiences is noticeable. Those who have played a role of facilitor in this process have been all non-governmental organizations. 
Finally, the consolidation of this new rurality not only requires an appropriation of the patrimonial values by the regional society, but also the protection of these values.12 In addition, it requires a deep change in the thinking of civil society towards farming practices in general and food products in particularly.

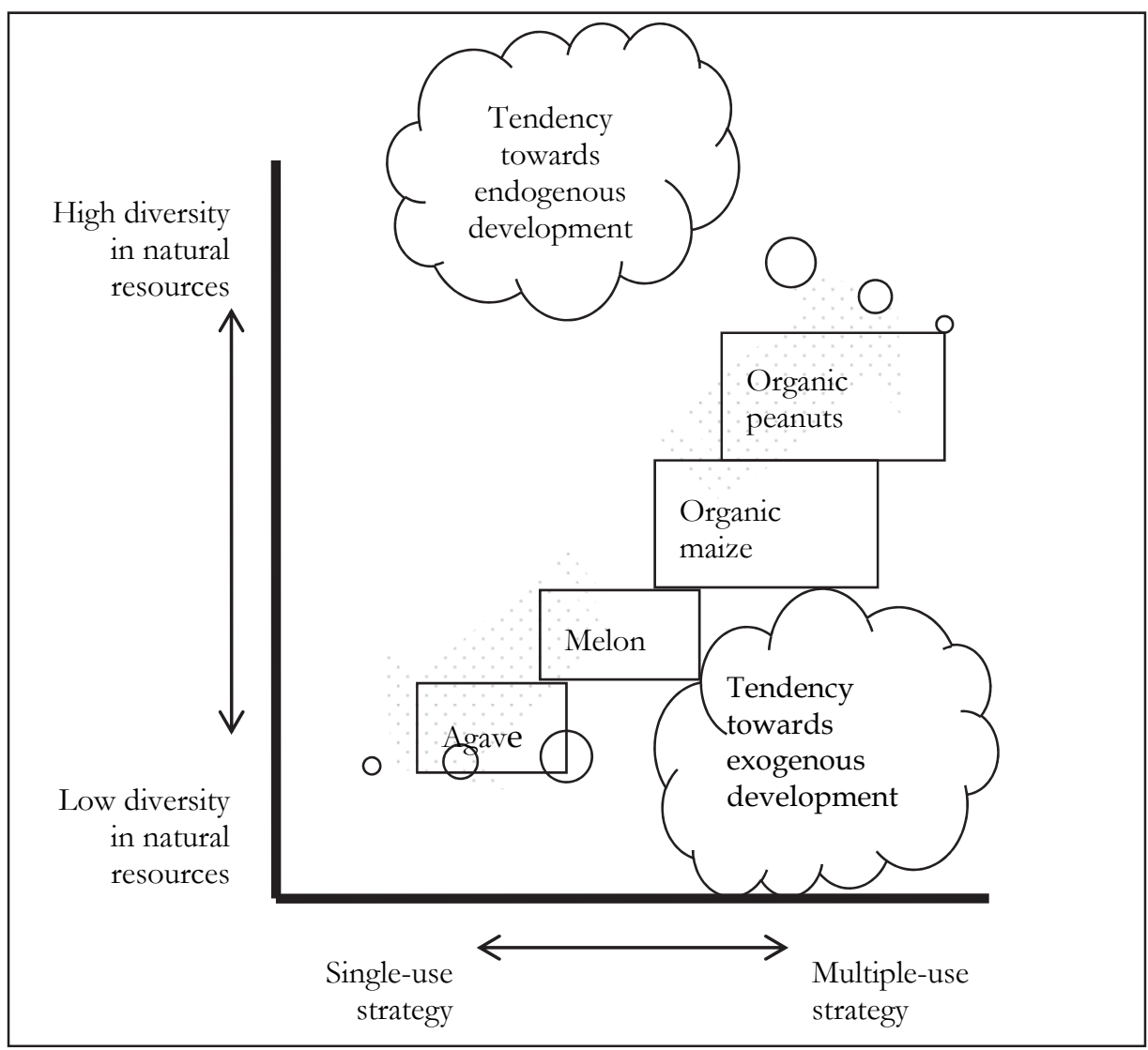

Fig. 5. Qualitative sustainability assessment of four crops

\section{Acknowledgements}

The author acknowledges the University of Guadalajara and the international program on research collaboration NCCR North South for their support.

12 Some of the mechanisms to protect the different initiatives of endogenous rural development might be the origin denominations in the case of the productive process, or the certification of the final products (Casablanca and Linck 2004). 


\section{References}

Broekhuizen, R. \& J.D. van der Ploeg. (1995). Design methods for endogenous rural development Wageningen. Agricultural University, Internal report, Wageningen

Calva, J.L. (1993). 'El Modelo de desarrollo agropecuario impulsado mediante la ley agraria y el TLC'. In: Alternativa para el campo mexicano, Calva J.L. (coord.), 15-43, Edición Fontamara, ISBN 9684761600,México, D.F.

Carabias, J \& E. Provencio (1993). 'Hacia un modelo de desarrollo agrícola sustentable'. Pp. 45-59 in: Calva J.L. (Coord.). Alternativas para el campo mexicano. Tomo II. FontamaraFES. México.

Casablanca, F. A. \& T. Linck. (2004). Tipificación de alimentos y apropiación de recursos patrimoniales. Paper presented at the Congreso Internacional Agro-empresas rurales y Territorio (ARTE), Toluca, Estado de México, 1-4 de diciembre de 2004.

Cortez, R. C., Concheiro, B. L. \& León L. A. (1994). Los pueblos indios frente a la globalidad: efectos y respuestas. Paper presented at the Coloquio, Impacto de la Modernización en el Ámbito Laboral a Finales del Siglo XX. Xalapa, Veracruz. Universidad Veracruzana.

Enríquez, M. (2000). Los proyectos productivos para mujeres: Del discurso del desarrollo a las experiencias vividas. El Colegio de la Frontera Sur. Tesis de maestría.México: San Cristóbal de las Casas:

Esteva, G. \& C. Marielle (Coord.). (2003). Sin maíz no hay país. Comité sin Maíz no hay País/CONACULTO. ISBN: 970-35-0434-5, México, D.F.

Figueroa B., P., G. Cruz S., V.M. Villalvazo L., \& P.R.W. Gerritsen. (2003). Tecnología apropiada para el desarrollo endógeno: la estufa Lorena y el ahorro de leña en dos comunidades rurales del Occidente de México. Presentation delivered at the X Simposio sobe Conservación, Manejo de Recursos Naturales y Desarrollo, organizado durante los días Noviembre, 24-27, en Autlán, Jal., México.

Figueroa B., P. R. Moreno, P.R.W. Gerritsen \& V. Villalvazo. (2004). Desarrollo endógeno y seguridad alimenticia: experiencia del ejido de Ayotitlánen el Occidente de México. Paper presented at the Congreso Internacional Agro-empresas Rurales y Territorio (ARTE), Toluca, Estado de México, 1-4 de diciembre de 2004.

Gerritsen, P.R.W. (2010). Perspectivas campesinas sobre el manejo de los recursos naturales. Mundiprensa/Universidad de Guadalajara. ISBN: 9786077699095, Mexico city.

Gerritsen, P.RW. (2006). On endogenous rural development and new images of rurality in western Mexico. Paper presented at the XI International Congress of the Latin American Studies Association, San Juan, Puerto Rico, March 15-18, 2006.

Gerritsen, P.R.W. (2002). Diversity at Stake. A farmer's perspective on biodiversity and conservation in Western Mexico. Wageningen Studies on Heterogeneity and Relocalization 4. ISBN: 9067546836, Wageningen.

Gerritsen, P.R.W., M. Montero C. \& P. Figueroa B. (2003). ‘Percepciones campesinas del cambio ambiental en el Occidente de México'. Economía, Sociedad y Territorio Vol. II, Núm. 14, Julio-Diciembre de 2003. ISSN: 1405-8421

Gerritsen, P.R.W., G. Cruz, V. Villalvazo, \& P. Figueroa. (2004). "Productos regionales" en el Occidente de México: ¿respuestas locales frente a la globalización económica? Paper presented at the Congreso Internacional Agro-empresas rurales y Territorio (ARTE), Toluca, Estado de México, 1-4 de diciembre de 2004.

Gerritsen, P.R.W., V. Villalvazo L., P. Figueroa B., G. Cruz S. \& J. Morales H. (2005a). Productos Regionales y Sustentabilidad: Experiencias de la Costa Sur de Jalisco. Paper presented at the Vto Congreso de la Asociación Mexicana de Estudios Rurales (AMER), Ciudad de Oaxaca, Oaxaca, 25 al 28 de mayo de 2005. 
Gerritsen, P.R.W, V. M. Villalvazo, P. Figueroa B. \& G. Cruz S. (2005b). Fortaleciendo procesos endógenos en la Costa Sur de Jalisco: Imágenes de una nueva ruralidad emergente. Paper presented at the I Foro Académico Interinstitucional: "Diálogos sobre el Sur de Jalisco: Actualidad y Futuro del Desarrollo", Zapotlán el Grande, Jalisco, 22 de febrero de 2005.

Gónzalez, F., R. (2006). Analisis de sustentabilidad de cuatro cultivos en el ejido La Cienéga, Municipio de Limón. Autlán: Centro Universitario de la Costa Sur, Universidad de Guadalajara. B.Sc.-thesis.

Gúzman C., G., M. González de Molina \& E. Sevilla G. (2000). Introducción a la agroecología como desarrollo rural sostenible. Ediciones Mundi-Prensa. ISBN: 8471148706, Madrid/Barcelona/México.

Halweil, B. (2002). Home grown. The case for local food in a global market. Washington, D.C.: Worldwatch Paper 163.

Heijden, D. van der, P. Camacho, C. Marlin \& M. Salazar G. (2004). Guía metodológica para el análisis de cadenas productivas. Quito: Ruralter/SNV/CICDA/Intercooperation.

Jansen, K. \& S. Vellema. (2004). Agribusiness and society. Corporate responses to environmentalism, market opportunities and public regulation. London/New York: Zed Books.

Kabeer, N. (1998). "Conectar, extender, trastocar: El desarrollo desde una perspectiva de género", en: Naila Kabeer, (ed.). Realidades trastocadas. Las jerarquías de género en el pensamiento del desarrollo. México. Universidad Autónoma de México.

Long, N. (2001). Development sociology. Actor perspectives. London and New York: Routledge.

Long, N. \& A. Long (Eds). (1992). Battlefields of knowledge. The interlocking of theory and practice in social research and development. London y New York: Routledge Publishers.

Malischke, T.K., R. González F. \& P.R.W. Gerritsen. (2005). Percepciones campesinas sobre la degradación ambiental Una comparación de agricultores orgánicos y convencionales en el ejido de La Ciénega, Municipio de El Limón, Jalisco, México. Paper presented at the Vto Congreso de la Asociación Mexicana de Estudios Rurales (AMER), Ciudad de Oaxaca, Oaxaca, 25 al 28 de mayo de 2005.

Meulen, H. van der. (1999). Streekproducten in Nederland. Inventarisatie, criteria, certificering en case studies. Wageningen: Leerstoelgroep Rurale Sociologie, Wageningen Universiteit.

Morales H., J. (2001). Construyendo la sustentabilidad desde lo local: la experiencia de la Red de Alternativas Sustentables Agropecuarias de Jalisco. Guadalajara: ITESO. Technical report.

Morales H., J. (2003). Desarrollo rural alternativo en el sur de Jalisco: experiencias hacia la sustentabilidad rural. ITESO: Informe final de investigación.

Morales H., J. (2004). Sociedades rurales y naturaleza, En busca de alternativas hacia de la sustentabilidad. Guadalajara: ITESO/Universidad Iberamericano.

Moser, C.O.N. (1993). Gender planning and development. Theory, practice and training. London and New York: Routledge Press.

Muñoz, C. \& A. Guevara. (1997). Pobreza y Medio Ambiente. Pp. 165-149 in Martínez, G. (Comp.) Pobreza y Política Social en México. México, D.F.: Fondo de Cultura Económica /ITAM.

Ploeg, J.D. van der. (1990). Labor, markets and agricultural production. Boulder, San Francisco and Oxford: Westview Press.

Ploeg, J.D. van der. (1992). 'The reconstitution of locality: technology and labour in modern agriculture'. Pp. 19-43 in Marsden, T., R. Lowe and S. Whatmore (Eds) Labour and locality: uneven development and the rural labour process. London: David Fulton Publishers. Critical perspectives on rural change series, IV.

Ploeg, J.D. van der. (1994). 'Styles of Farming: an introductory note on concepts and methodology'. Pp. 7-30 in Long, A. and J.D. van der Ploeg (Eds) Born from within. Practice and perspective of endogenous rural development. Assen: Van Gorcum Publisher. 
Ploeg, J.D. van der, A. Long \& J. Banks. (2002). Living countrysides. Rural development processes in Europe: the state of the art. Doetinchem: Elsevier.

Ploeg, J.D. van der. (1997). 'On rurality, rural development and rural sociology.' Pp. 39-73 in Haan, H. de and N. Long (Eds) Images and realities of rural life. Wageningen perspectives on rural transformations. Assen: Van Gorcum Publishers.

Ploeg, J.D. van der \& A. Long. (Eds.). (1994). Born From within. Practice and perspectives of endogenous rural development. Assen, Paises Bajos: Van Gorcum.

Pretty, J.N. (1995). Regenerating agriculture: policies and practice for sustainability and selfreliance. London: Earthscan Publications Ltd.

Restrepo, J. (1998). La mejora campesina, una opción frente al fracaso de las granjas integrales didácticas, Servicio de Información Mesoamericano sobre Agricultura Sostenible, Colección Agricultura Ecológica para Principiantes 4.

Reyes G., C., V.M. Villalvazo L, M. Enríquez M. \& P. Figueroa B. (2004). Mujeres en la búsqueda de alternativas productivas en la comunidad indígena de Cuzalapa, reserva de la biosfera Sierra de Manantlán. Paper presented at the II Coloquio Nacional de la Red de Estudios de Genero del Pacifico Mexicano, durante los días 26 y 27 de marzo de 2004 en la ciudad de La Paz en Baja California Sur.

Rist, S. (2004). 'Endogenous development as a social learning process.' COMPAS Magazine Sept. 2004: 26-29.

Saxe-Fernández, J. (1998). ‘Neoliberalismo y TLC: ¿Hacia ciclos de guerra civil?’. Pp. 87-124 in: de Pina, G. J.P y J. Alba, G. (Eds). Globalización, Crisis y Desarrollo Rural en América Latina México, D.F.: Colegio de Postgraduados Universidad Autónoma de Chapingo. Memorias de sesiones plenarias del V Congreso Latinoamericano de Sociología Rural.

Schwentesius, R., M.A. Gómez C., J.L. Calva T. \& L. Hernández N. (Coord.). (2003). ¿El campo aguanta más? Texcoco: Universidad Autónoma de Chapingo / La Jornada.

Swagemakers, P. (2002). Verschil maken. Novelty-productie en de contouren van een streekcooperatie. Wageningen, Países Bajos: Circle for European Studies/Leerstoelgroep Rurale Sociologie.

Toledo, V.M. (1990). 'The ecological rationality of peasant production.' Pp. 53-60 in Altieri, M.A. and S.B. Hecht (Eds) Agroecology and small farm development. Boca Raton/Ann Arbor/Boston: CRC Press.

Toledo, V.M. (1995). Campesinidad, agroindustrilidad y sostenibilidad. Los fundamentos ecológicos e históricos del desarrollo rural. México City: Interamerican Group for Sustainable Development of Agriculture and Natural Resources. Report No. 3.

Toledo, V.M. (2000). La Paz en Chiapas. Ecología. Luchas indígenas y modernidad alternativa. Mexico City: Ediciones Quinto Sol/UNAM.

Toledo, V.M. (2003). Ecología, espiritualidad y conocimiento. De la sociedad del riesgo a la sociedad sustentable. México, D.F.: Universidad Iberamericana/PNUMA.

Villalvazo L., V.M., P.R.W. Gerritsen, P. Figueroa B. \& G. Cruz S. (2003). ‘Desarrollo rural endógeno en la Reserva de la Biosfera Sierra de Manantlán, México.' Sociedades Rurales. Producción y Medio Ambiente 4 (1): 41-50.

Villalvazo L., V.M., P.R.W. Gerritsen, P. Figueroa B., R. Ramirez P. \& L. Córdoba R. (2005). Alternativas productivas y desarrollo endógeno en el Occidente de México. Paper presented at the I Congreso Internacional "Casos Exitosos de Desarrollo Sostenible del Trópico, Xalapa, Veracruz, México del 2 a 4 de mayo de 2005.

Waters, M. (1995). Globalization. London and New York: Routledge.

Wiskerke, J.S.C. \& J.D. van der Ploeg. (2004). Seeds of transition. Essays on novelty production, niches and regimes in agriculture. Assen: Royal van Gorcum. 


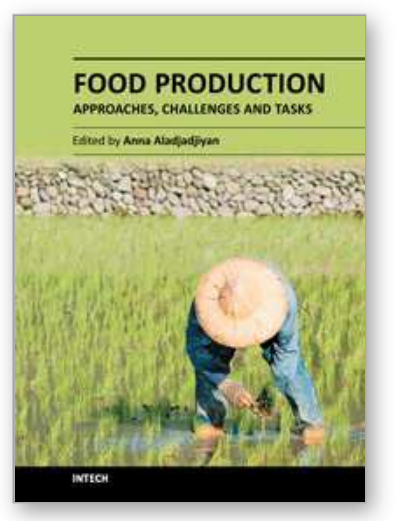

\author{
Food Production - Approaches, Challenges and Tasks \\ Edited by Prof. Anna Aladjadjiyan
}

ISBN 978-953-307-887-8

Hard cover, 270 pages

Publisher InTech

Published online 20, January, 2012

Published in print edition January, 2012

This book is devoted to food production and the problems associated with the satisfaction of food needs in different parts of the world. The emerging food crisis calls for development of sustainable food production, and the quality and safety of the food produced should be guaranteed. The book contains thirteen chapters and is divided into two sections. The first section is related to social issues rising from food insufficiency in the third world countries, and is titled "Sustainable food production: Case studies". The case studies of semi-arid Africa, Caribbean and Jamaica, Burkina Faso, Nigeria, Pacific Islands, Mexico and Brazil are discussed. The second section, titled "Scientific Methods for Improving Food Quality and Safety", covers the methods for control and avoidance of food contaminants. Substitution of chemical treatment with physical, rapid analytical methods for control of contaminants, problems in animal husbandry related to diary production and hormones in food producing animals, approaches and tasks in maize and rice production are in the covered by 6 chapters in this section.

\title{
How to reference
}

In order to correctly reference this scholarly work, feel free to copy and paste the following:

Peter R.W. Gerritsen (2012). Strengthening Endogenous Regional Development in Western Mexico, Food Production - Approaches, Challenges and Tasks, Prof. Anna Aladjadjiyan (Ed.), ISBN: 978-953-307-887-8, InTech, Available from: http://www.intechopen.com/books/food-production-approaches-challenges-andtasks/strengthening-endogenous-regional-development-in-western-mexico

\section{INTECH}

open science | open minds

\section{InTech Europe}

University Campus STeP Ri

Slavka Krautzeka 83/A

51000 Rijeka, Croatia

Phone: +385 (51) 770447

Fax: +385 (51) 686166

www.intechopen.com

\section{InTech China}

Unit 405, Office Block, Hotel Equatorial Shanghai

No.65, Yan An Road (West), Shanghai, 200040, China

中国上海市延安西路65号上海国际贵都大饭店办公楼 405 单元

Phone: +86-21-62489820

Fax: $+86-21-62489821$ 
(C) 2012 The Author(s). Licensee IntechOpen. This is an open access article distributed under the terms of the Creative Commons Attribution 3.0 License, which permits unrestricted use, distribution, and reproduction in any medium, provided the original work is properly cited. 